\title{
The political integration of newcomers of Latin American origin to Canada: An examination of the role and relevance of prior knowledge
}

\author{
Neyda H. Long and Andrew S. Hughes \\ University of New Brunswick
}

\begin{abstract}
The purpose of this research was to map the understanding of the concept of political participation held by newcomers to Canada from countries from Spanish-speaking Latin America. The relevance of the work lies in the view that this prior knowledge plays a significant role in how newcomers adjust to political activity in the new society. Canada has tacitly recognized the full spectrum of participation and belonging for newcomers, including its economic, social and political dimensions, but the historical emphasis in policies and programs has been upon economic and social integration. Here, attention is directed to the issue of integration into the political fabric of the nation. The research employed a phenomenographic method and data were generated from 70 individuals from 30 families. The findings revealed that the participants attach considerable importance to political participation whether through conventional electoral politics or through grass-roots actions. For the study participants, the concept of political participation includes components related to emotional commitments, community involvement, social action, freedom of conscience, the power to make a difference and identification with Canada. The findings show that the motivational force to belong channels the preferred forms of political engagement.
\end{abstract}

Key words: Political participation, citizenship, social studies, immigration, Latin-Canadians, prior knowledge

RESUMEN

El propósito de esta investigación fue mapear las concepciones que tienen los inmigrantes latinoamericanos en Canadá sobre participación política. La importancia de este estudio se encuentra en el hecho de que este conocimiento previo juega un papel fundamental en la adaptación de los inmigrantes latinoamericanos a la actividad política en la nueva sociedad. Canadá, ha reconocido tácitamente la importancia de la pertenencia y la participación económica, social y política de los recién llegados. Sin embargo, históricamente el énfasis en políticas y programas ha sido colocado en la integración económica y social. En nuestro estudio, la atención está dirigida hacia el problema de la integración política dentro de la estructura del sistema político canadiense. La investigación utilizó el método fenomenográfico y el procesamiento de datos surgió de entrevistas con 70 individuos provenientes de 30 familias. Los hallazgos revelaron que los participantes dan gran importancia a la participación política sea en la forma de actividades de orden electoral o a través de actividades comunitarias. Para los participantes del estudio, el concepto de participación política incluye los componentes relacionados con lazos emocionales, acción orientada 
hacia la comunidad, acción social, libertad de conciencia, el poder de hacer alguna diferencia y el nivel de identificación con Canadá. Los resultados de este estudio demuestran que la fuerza motivacional de la pertenecencia canaliza las formas y prioridades de la participación política.

Descriptores: Participación política, ciudadanía, estudios sociales, inmigración, latino-canadienses, conocimiento previo

\section{RÉSUMÉ}

Le but du présent papier est de tracer la compréhension du concept de la participation politique qu'ont les nouveaux venus des pays de l'Amérique latine de langue espagn ole au C anada. Q uand les nouveaux venus arrivent au $C$ anada, eux ainsi que leur nouveau pays sattendent à un processus d'intégration rapide et réussi. Le C anada a tacitement reconnu l'éventail complet de participation et d'appartenance, y compris ses dimensions économiques, sociales et politiques. D ans cette recherche, on décrit la compréhension des manières de comprendre la participation politique qu'ont les nouveaux venus d'origine latino-américaine au Canada. La pertinence de ce travail de recherche se trouve dans la perspective que ces connaissances antécédantes jouent un rôle important dans la façon dont les nouveaux venus s'adaptent à l'activité politique dans la nouvelle société. La recherche a utilisé une méthode phénoménographique et les données ont été générées à partir de 70 individus provenant de 30 familles. Les résultats ont révélé que les participants attachent passablement d'importance à la participation politique, que ce soit par la politique électorale conventionnelle ou par laquelle ils interprètent le concept de la participation politique. Parmi ces filtres se trouvent des composantes reliées aux engagements, à la participation communautaire, à l'action sociale, à la liberté de conscience, à la capacité de faire une différence et à l'identification au $C$ anada. Les résultats démontrent que les filtres servent de manières diverses à canaliser les formes privilégiées d'en gagement politique.

Mots-cléfs: Participation politique, citoyenneté, étude sociales, immigration, latino-canadiens-iennes, connaissance préalable

\section{Introduction}

W HEN NEWCOMERS SET FOOT IN CANADA, both they and their new country look forward to a swift and successful process of integration. The expectation is for a period of adaptation and adjustment leading ultimately to fitting in and belonging. Indeed, during the immigration screening process, considerable attention is paid to those attributes generally considered linked to succesfful integration: level of education, skills and training to be brought to the workforce, language proficiency, family members al ready in C anada, and even the notion of 'adaptability.' To help newcomers fit in, governments at all levels provide a range of services, mostly related to job training and language. Working through a range of surrogate agencies (Sears, 1996) from the volunteer sector, such as church and local multicultural associations, considerable effort is expended to assist newcomers in the initial settlement process. For the most part, the pervading conception of the process sees newcomers achieving a measure of economic security and well-being as well as finding a place in the social fabric of the new society.

For most newcomers, some degree of successful economic and social integration produces a press toward citizenship (Bloemraad, 2002); however, the sense of belonging and commitment implied in citizenship requires considerably more than some measure of economic and social integration. After all, slaves have been well integrated both economically and socially into the societies where that institution has existed. Assumption of the rights and responsibilities of citizenship entails not merely the acceptance of the 
protection of the state but also a willingness to seize the responsibility for shaping the character of the state, at least in democratic societies. It requires the development of the capacities and dispositions to participate in the affairs of the state. Such "widespread, informed and effective participation [has been singled out as] the hallmark of democracy..." (M ishler \& Clarke, 1990, p. 158). For newcomers, it means that integration is more than the capacity to contribute to the economy or to enrich the social fabric of the nation; it includes a successful integration into the political life of the nation, whether in the form of participation in conventional electoral politics or in the grassroots politics of political and social activism (H ardy-Fanta, 1993).

From time to time, there has been considerable hand-wringing in many democracies, including $\mathrm{C}$ anada, concerning the relatively low levels of political participation by the population at large. Canadians, born, raised and nurtured in a culture that purportedly values and promotes active participation in the political life of the nation, seem to encounter significant obstacles to becoming active participants. What of new $C$ anadians whose experience and education might even have been antithetical to the goal of active participation? W hile research related to the economic and social integration is well established in Canada (for example, Abu-Laban, 1998; C ampbell, 2000; Jones-C orrea, 1998; Kalbach \& Kalbach, 1999; K azemipur \& H alli, 2000; M ata, 1999; Pendakur \& Pendakur, 1998), there has been little formal examination of the integration of newcomers into the country's political life. Today, $C$ anada is receiving the most diverse group of immigrants in its history. With the passing of the era of "angloconformity" (Kymlicka, 1998; 2000), more newcomers than ever before can arrive with little understanding of the principles of liberal democracy in $\mathrm{C}$ anada or elsewhere. Yet, we hold to the notion of a swift and successful integration that presumably includes political integration. H ow can we construe the process of political integration as experienced by newcomers so as to both understand and support the adjustments and accommodations that inevitably must be made by them and the receiving society? In this paper, we suggest that the concept of prior knowledge is of critical importance, possessing both a theoretical significance and a practical importance in relation to the successful integration of newcomers and we report some research that begins to map theintellectual terrain.

\section{Prior knowledge and conceptual change}

When newcomers arrive in $C$ anada, they bring with them baggage that is as much intellectual and emotional as it is material. They bring with them understandings of how the world works, including the world of politics and political participation. These preconceptions are largely rooted in the life-world of their countries of origin but they also consist of their expectations of how the world works in the new society. This prior knowledge serves to screen or interpret experience in the new situation. When encountering any new situation, an individual "sees" it in light of their existing schemata "mental data structures which represent our knowledge about objects, situations and events" (Rumelhart \& O rtony, 1977, p. 87). These data structures inform a person's perspective both descriptively and normatively. $N$ ot only will they suggest, for example, 
who may hold elected office but they also shape judgments concerning who should be ableto hold elected office. Similarly, they shape a host of concepts that collectively comprise the spirit of democracy in a free society. This is not to say that newcomers arrive in C anada without concepts such as tolerance, due process, rights of privacy or of speech, assembly, conscience and so on. It is just that their concepts may be somewhat different; not completely synchronous with prevailing notions in the receiving society. Because this prior knowledge of the newcomer may not be sufficiently similar to ideas in the receiving society, it is not always adequate in explaining to newcomers the things that they see, in providing an understanding for the way people behave, for comprehending why things turn out the way they do. To begin to integrate into the new world, the newcomer has to take on board the ideas needed to make sense of the new situation or, at least, they have to begin a process of modification and accommodation.

Assisting newcomers in making adjustments to the new society is often seen as having an educative component, and it is from research on learning that much of our understanding of prior knowledge has developed. Torney-Purta (1991) points out that when a learner encounters a new situation, the intellectual framework that they use to interpret it may be inadequate. She refers to this as a "naïve theory" in the sense that it may be incomplete or inadequate. It is not necessarily wrong, but simply incomplete and naïve as opposed to sophisticated. In this sense, these are descriptive rather than normative terms.

Through anecdote and casual observation we know that newcomers can often integrate very quickly into the economic and social fabric of the nation but that political integration proves a greater challenge. 0 ur hypothesis is that this may well be related to the sort of prior knowledge that newcomers bring with them and the opportunities that they encounter for acquiring new knowledge. In this paper, we set out to map the range and depth of understandings of the idea of political participation held by newcomers and to relate this prior knowledge to their perceptions of the opportunities for and obstacles to political integration in Canada. By elucidating newcomers' understandings of aspects of political life, we believe that a stronger foundation can be established for policies and programs that would seek to facilitate their swift and succesful integration across the full spectrum of citizenship - economic, social and political.

\section{Research method}

The research approach used in the study was phenomenographic in nature ( $M$ arton, 1981). Phenomenography deals with how people conceptualize reality. The essential purpose of this study was to describe how Latin American newcomers understand the experience of political participation in C anada. The challenge was to lay bare the intellectual schemata that shape the person's conceptualization of political participation.

\section{The phenomenographic method}

For M arton (1996), "Phenomenography is a research method for mapping the qualitatively different ways in which people experience, conceptualize, perceive, and under- 
stand various aspects of, and phenomena in, the world around them" (p.31). Renström (1988) suggests that the essence of the phenomenographic method lies in the verbal statement, which he says should be studied in two ways: "as it is" and in terms of "the meaning it expresses." The verbal statement displays, at least in part, how someone has conceptualized something, which through skillful questioning and probing can provide a vivid rendering of the conceptualization. The conceptualizations themselves are a product of the interaction of the psychological world of the individual and the outside world that is encountered.

The phenomenographic interview aims to disclose how individuals understand a phenomenon (Bruce, 1994; Kvale, 1996) and then to map the invariances across those individuals. The purpose is to unveil variations in the "how" and "what" aspects of each participant's understanding. The interview seeks to elicit the qualitatively different conceptions of the phenomenon being studied as these are experienced or understood by the interviewee.

Interviews were conducted with 70 individuals from 30 families. Participating families were selected using two major criteria: 1) each family was of Spanish-speaking Latin American origin and 2) included at least one adolescent (12-15 years) or youth (16-20 years) and one parent willing to be interviewed. Potential participants were identified using a snowball sampling technique and were contacted initially through a phone call in Spanish.

The interview process used in this study involved a semi-projective data collection technique in that it used photographs to help focus participants' talk about their perceptions and conceptions of political participation in C anada. Participants were invited to comment on one or more of a variety of situations. The intention, through careful probing, seeking elaboration and clarification, was to expose the major features of the individual's understanding of the phenomenon. The procedures used here followed the recommendations of G reenstein and Tarrow (1970) and of Knutson (1973). The pictorial material used as stimulus material was deliberately ambiguous, permitting multiple interpretations and served also to stir the imagination and to force the participant to deal in their own way with significant situations involving political participation.

Table 1. Participants by Age and Gender

Participants by $A g e$ and $G$ ender

\begin{tabular}{llll}
\hline Age G roups & Females & M ales & Total \\
Adults & $23(72 \%)$ & $9(29 \%)$ & $32(46 \%)$ \\
Adolescent (12-15 years) & $10(53 \%)$ & $9(47 \%)$ & $19(27 \%)$ \\
Youth (16-20 years old) & $12(63 \%)$ & $7(37 \%)$ & $19(27 \%)$ \\
Total people interviewed & $45(64 \%$ & $25(36 \%)$ & $70(100 \%)$ \\
\hline
\end{tabular}

The goal of the analysis was to determine the extent to which the participants shared a similar intellectual schema of the concept of political participation. The analysis was 
conducted at three levels. Level one required an identification of utterances that revealed any aspect of a participant's thinking about political participation. For the purposes of coding, an utterance was construed as a discrete unit of thought. Philip (1976) has described it as "a verbal manifestation that conveys a meaning or evidence of understanding" (p.7). Essentially, it is a unit of talk that is 'on topic.' W hen a participant makes a shift to a new topic, the utterance is at end. Each utterance was assigned codes reflecting aspects of the concept that it addressed. $M$ anagement of data at this stage was facilitated through the use of the $\mathrm{N}$ vivo software package (Richards, 1999).

Level two of the analysis involved identifying broader categories of description based on the utterances. For example, if examination of a participant's utterances related to political participation revealed several focusing on one dimension of the concept then they would be designated as being reflective of a $C$ ategory of D escription. Typically, a transcript would reveal between four and seven major categories of description that dominated an individual's thinking about political participation. As such they constituted the major elements in their intellectual schema for the concept.

Level three of the analysis required examination of the extent to which the same or largely similar categories of description occurred across the participants comprising the study population. We have referred to these recurring conceptions across participants as "themes." T his conforms to Eisner's (1991) use of the term to describe "those recurring messages construed from the events observed" (p.189). There is no generally accepted standard of recurrence required for categories of description to be designated as themes. $\mathrm{H}$ ere, we have chosen to designate as themes those categories of description that are common to more than fifty percent of the participants.

\section{Findings}

\section{Categories of Description}

The findings show that when the newcomers in this study think about the concept of political participation, they tend to construe the idea in terms of categories of description with both cognitive and affective elements. Variations among the study participants were reflected in two ways: first, the categories of description (elements) that comprised their thinking about participation; and second, the configuration of those elements. Simply put, although similar elements were usually present in participants' thinking about political participation, the relative importance attached to them varied. Still, comparison across participants allowed the identification of four dominant modes of thought that constituted the qual itatively different ways in which participants understand the idea of political participation.

Elements with a strongly cognitive dimension consisted of: (i) electoral politics, (ii) grassroots participation, and (iii) purposive action. Those of the affective dimension comprised (i) the power to make a difference, (ii) a sense of belonging and (iii) 'following your heart.' The data were examined for differences between young people and adults and between newcomers whose country of origin had a recent history that was democratic or non-democratic. No observable systematic differences could be detected between groups (See figure 1). 

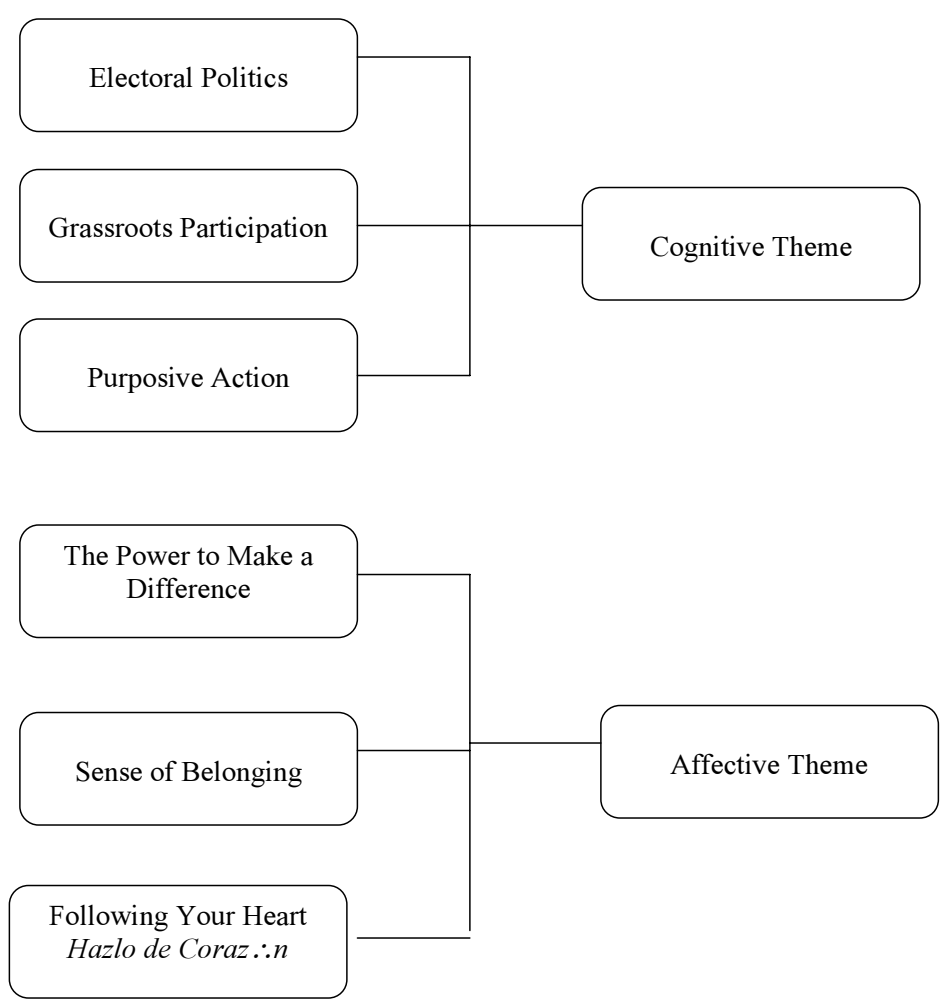

Figure 1. 0 verview of Results

\section{The Cognitive Dimension}

The parameters of the understanding of political participation, in an intellectual sense, were displayed in terms of activities related to electoral politics and in terms related to grassroots participation of a political nature. The participants distinguished between activities falling into the two realms. At the same time, these two elements of the schemata were attached to a third, purposive action. Both electoral and grassroots politics were understood by participants as activities designed to accomplish a political end.

\section{Electoral Politics}

When confronted with photographs representing a variety of forms of engagement in the community, the participants readily recognized their political character. Furthermore, their comments showed that they were familiar with the full gamut of modes of participation represented in the photographs and could suggest others that could easily fit the typology portrayed in Figure 2. The distinctions that they drew focused, first of all, on a recognition of activities that were overtly political in the sense that they addressed matters of electoral politics such as voting, running for office, and working for a political party. 


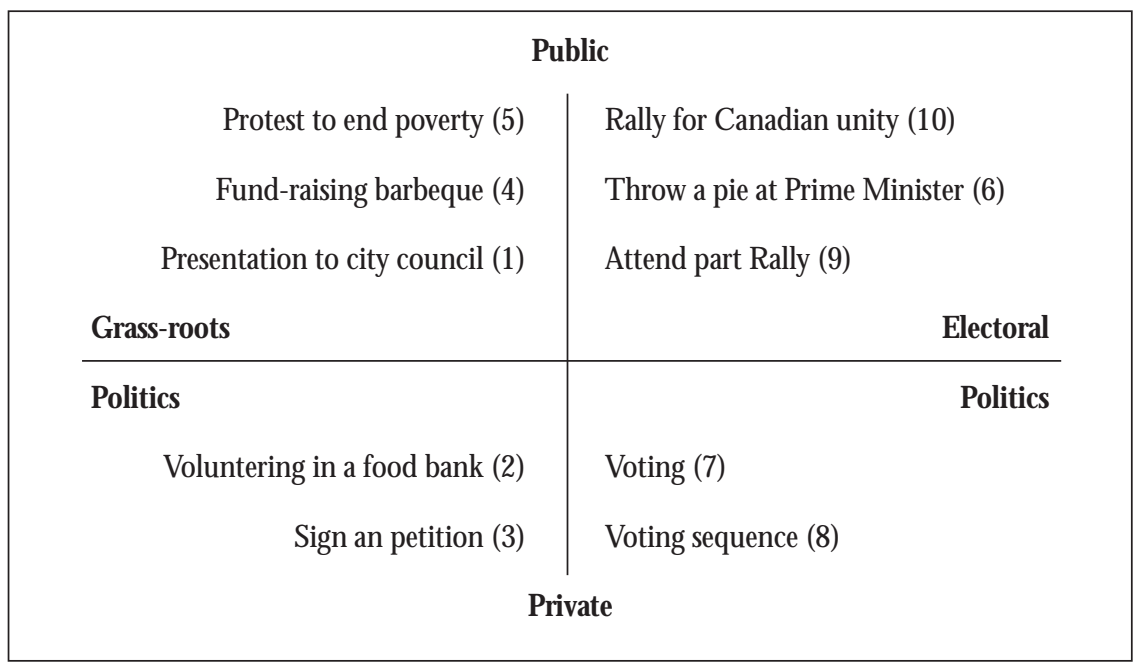

Figure2. Typology of the pictures

For most of the participants, even those not yet of voting age, the act of voting was construed as central to the act of political participation. It was often described as a "duty" or an "obligation."

Through the vote you express your will. Voting is the most direct expression even though there are people who did not believe in voting in my country. I used to vote blank. This is an expression of protest. I did not agree with the candidates and abstention is also a form of protest and a form of political expression. (female/adult)

$M$ any also saw voting as the culminating act in a process of choice that demands that the elector be informed; that electors deliberately seek out information that will help them make good use of their vote. Thus, discussions of free choices in voting would often slide toward consideration of the importance of free speech and freedom of the press as central to the process of nurturing an informed electorate.

While voting was viewed as the central act of political participation, the importance of running for office and working directly for political parties was also recognized. For the most part, however, the adult study participants quickly identified "their place" which in the world of electoral politics tended to be where they are not visible. For most participants "visibility" was located in their ability, or perceived lack of ability, to speak English, and occasionally French. Lack of language capability was considered a hindrance in public participation in the electoral process but working "behind the scenes" for a political party was an equalizer. Study participants generally saw a leadership role as exceeding both their grasp and their aspirations, though they often hoped that "my child who has been educated in Canada" might one day be considered for office. There is an almost uniform expectancy of opportunity for their children that they do not hold for themselves. 


\section{Grassroots Participation}

The category named "grassroots participation" represents a coalescence of ideas related to volunteering, helping others, and "helping in the community." Adult participants, in particular, expressed a greater level of comfort with the idea of grassroots participation than with a role in electoral politics beyond voting. In some sense, the participation described here is viewed as non-political participation. M ost of the study participants considered it a "safe" area in the sense of being non-controversial. Assistance in food banks, school activities, and helping the needy were seen as areas where the atmosphere might be more welcoming and, indeed, this was what they reported. At the same time, these are arenas where the political skills of speaking, letter writing, and communicating by phone, fax and email can be learned and developed. H ere too, though, the newcomers saw themselves in assisting rather than leadership roles. $0 \mathrm{ften}$, there might be encouragement to children to take on greater responsibility but adults in this study population did not seek such roles themselves. Rather, there seems to be an acceptance of the value of contributing without seeking reward. Speaking of the role of volunteers in the community, one participant said, "T hey do not earn any money. They are volunteers. This is something that has merit, because they do it without self-interest" (male/adult). In some respects, the participants could see grassroots participation as a secure way of reaching out to the larger community without encountering the risks and rebuffs that might accompany a more public foray, as in theworld of electoral politics.

\section{Purposive Action}

Some of the photographs used as stimulus material showed citizens engaged in efforts to bring about political, economic and social change. These particular materials evoked the strongest response on the part of study participants. Certainly, all recognized that there can be issues within a society that demand action but they also had rather firm views concerning what might be considered appropriate ways of addressing such issues. For example, responding to a picture portraying a protest march against child poverty, one participant said, "it would be important to invite the whole community and to involve professionals from different fields... and to make the protest within the law..." (female/adult) Similarly, there was universal disapproval of a protester throwing a pie at the Prime $\mathrm{M}$ inister. Their comments on a range of mechanisms of public protest showed a broadly-based commitment to non-violent and legal means of dissent. For the adults, expressing dissent in any way was clearly a serious business. Young people did say that participation in some protest activities could land them in trouble but that they were mainly "fun activities... like being in a big party." Adults, however, saw such activities in a much more serious and even sinister light evoking memories, such as "disappearances," which caused them to be fearful of their children's participation and involvement. There was a clear understanding of the right of citizens to engage in public action but there was al so a clear sense of trepidation and apprehension. 


\section{The Affective D imension}

W hile the major cognitive elements of a generalized schema that would typify al most all participants included a distinction between electoral and grassroots politics and was under girded by the attribute of purposive action that attached to both, there were also significant affective elements that elaborated and refined the revealed schema. All of them serve as filters or even forces that press toward active political engagement as a responsibility and an obligation that accompanies membership in the new society, even if, at times it seems more like an associate membership rather than a full membership.

\section{The Power to M ake a D ifference}

Almost uniformly, study participants were of the view that political participation, in whatever guise, must be purposeful; that engagement must tend toward improvement of society generally and that it should not necessarily require any personal benefit. O ften this idea of purposeful participation was relayed in words associated with "the power to make a difference." O ne person signing a petition "might make a difference in the world" but they also recognized the power of numbers. Referring to a large public protest, one participant said "... this large number of people asking for a change can make a difference because it would not be the same if there were just ten people asking the government for a change... "Young people often expressed this commitment to trying to make a difference by being engaged. Their parents, while often advocating caution, were seen by children as offering support in helping their children to follow their dreams of helping others. Interestingly, the belief that their participation would make a difference was expressed more frequently by newcomers from non-democratic countries than those whose countries of origin were more democratic.

\section{Sense of Belonging}

The commentaries from several participants showed a close linkage between their sense of the efficacy of political participation and their attachment or sense of belonging to their new country. Speaking of a large public demonstration during the last Q uebec referendum on independence, one participant observed, "I have lived here for ten years but this is not my country. Therefore it [the demonstration] does not have great importance for me." For most, however, there is a nascent attachment even from the time of the application to immigrate. O ne newcomer was immersed in events from the moment of her arrival:

I arrived in Q uebec at a historic moment, just as Rene Levesque came to power. The struggle he initiated affected me as a C hilean... who had seen a lot of social and political struggle. It was marvelous to see the Q uebec community wake up to the fight... I did not come to $\mathrm{C}$ anada because of political unrest in $\mathrm{C}$ hile but I came at the same time as refugees who came for political reasons... M any of them came to Q uebec where they were welcomed with open arms and much affection. (female/adult) 
The nascent attachment felt by most newcomers does not readily develop into a sense of $\mathrm{C}$ anada as my country. Belonging means more than just the right to occupy a space and a place. It requires an element of acceptance that lies with native born $C$ anadians, something not al ways evident to newcomers and whose absence provides an explanation for the tendency in many immigrant groups to "stick together."

This is the feeling I have from the $C$ anadian people. They are very helpful. If you need them they are there to help but if you want to establish a friendship the way we would with a person from the same country, it is different... I respect $C$ anadians but they have their own culture (female/adult).

Canadians are largely seen as "serviceable" (willing to help) but not friendly (in the sense of establishing friendships.) "I think I count in this country. I can vote. We live here and work here and pay taxes here, the same as other $\mathrm{C}$ anadians, but is with less than a sense of full membership" (male/adult).

Caution was the note sounded by many participants when addressing political participation that might draw the ire or authority figures. "If he were one of my minority friends, I would suggest that he think before doing it because $C$ anada has been more than generous to let us in the country" (male/adolescent). Intellectually, the newcomers in the group were well aware that their "belonging" to $C$ anada was in some sort of legal or rights sense, but quite clearly there is an emotional reticence that inhibits a full sense of belonging. There was no resentment in the tone of the newcomers who expressed these views. Rather, an acceptance that belonging requires a level of comfort and adjustment on the part of the newcomer and the new society.

\section{Following Your H eart (hazlo de corazón)}

This was a theme that was strong for both adults and young people. It often emerged in response to a question from the interviewer asking: "Would you participate in an action like this?" or "W hat would you say to your child if they were going to engage in such an action?" This might refer to participation in a public protest that could be legal or illegal, and perhaps involve confrontation with police or even acts of violence. Adults, in particular, could articulate the relationship between such actions and the possession of freedom but were cautious and said that they might actively discourage their children or, at least, encourage them to explore other avenues. Both young people and their parents, however, were of the view that, in the final analysis, each person must follow their own heart; each person must live with their own conscience. Importantly, this element of understanding in the concept of political participation inevitably embraces an acceptance of some measure of diversity, even though its boundaries may not be clear. 


\section{Ways of Understanding}

The qualitatively different ways of understanding political participation among the study participants were associated not simply with the presence or absence of particular categories of description or elements of the intellectual schema but rather in the relative emphasis attached to them. A simple analogy is to be found in the heliocentric and geocentric universes of Galileo and the curia of Pope U rban VIII. W hile working with the same elements (the heavenly bodies), they arranged them differently to reflect two qualitatively different understandings of the operations of the universe. In this study, participants frequently demonstrated that their understanding of political participation consisted of the same or similar elements but that they were sometimes configured differently. The four different ways of understanding that are posited reflect different conceptions of the 'locus of participation;' that is, the element that tends to be central to the understanding adhered to.

\section{Participation as Confirmation of Belonging}

In this way of understanding political participation, actions flow from a prior sense of belonging. $\mathrm{H}$ ere, the belonging is intellectual rather than visceral though the associated actions can be intended to create a feeling of belonging rather than simply an understanding of belonging. The line of reasoning is that the newcomer has chosen $\mathrm{C}$ anada, has been accepted as a permanent resident of $\mathrm{C}$ anada, and might even have become $\mathrm{a}$ legal citizen. The newcomer can, therefore, claim a legitimate place in the new society from which flows a sense of obligation for the well-being of the new place and consequently a responsibility for shaping its character through the various means of political participation. The right to belong and the need to belong are core elements in any discussion of political participation in whatever guise.

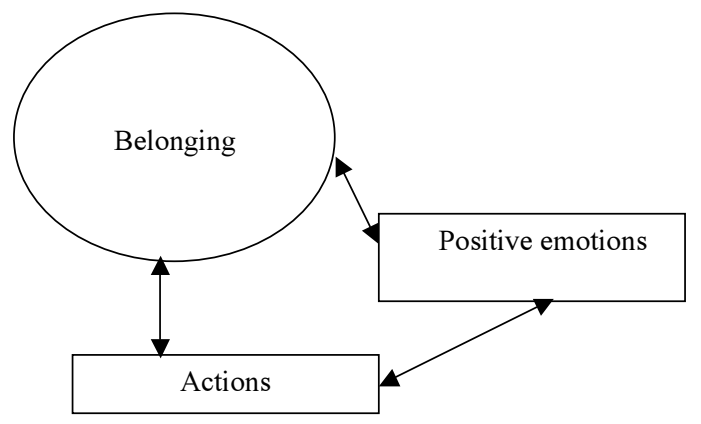

Figure 3. Participation as "belonging"

\section{Participation as Action}

In this way of understanding, participants reveal a strongly cognitive and rational perspective. First, they recognize a spectrum of ways of engaging politically, ranging from formal electoral participation to a wide range of grassroots activities. Second, they have assessed their own levels of access: more open at the grassroots, largely closed at the elec- 
toral, with newcomers confined to support roles in both. Exceptions are acknowledged but recognized as exceptions. There is recognition of inclusion but it is not total and must be earned. It is seen as the price that newcomers have traditionally paid.

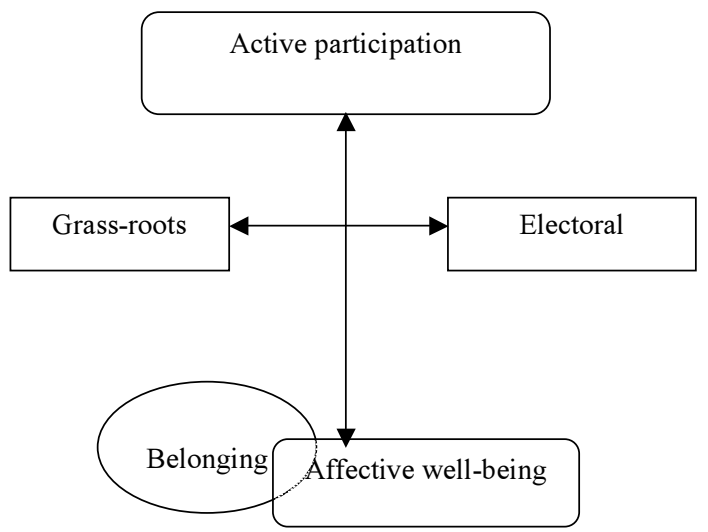

Figure 4. Participation as "action"

\section{Participation as M aking a D ifference}

$\mathrm{H}$ ere, political participation is interpreted in terms of its consequences. Political participation is understood in terms of the power to make a difference. In this way of understanding, considerable power is bestowed upon the individual whose voice, vote or signature on a petition might make a difference. H ence, the strong commitment to voting even though it is seen as a remote and indirect way of affecting daily life. A more direct way of affecting daily life is seen in the various forms of grassroots political action where newcomers expressed satisfaction in their capacity to see directly the results of their actions. In this way of understanding, a sense of empowerment falls at the core.

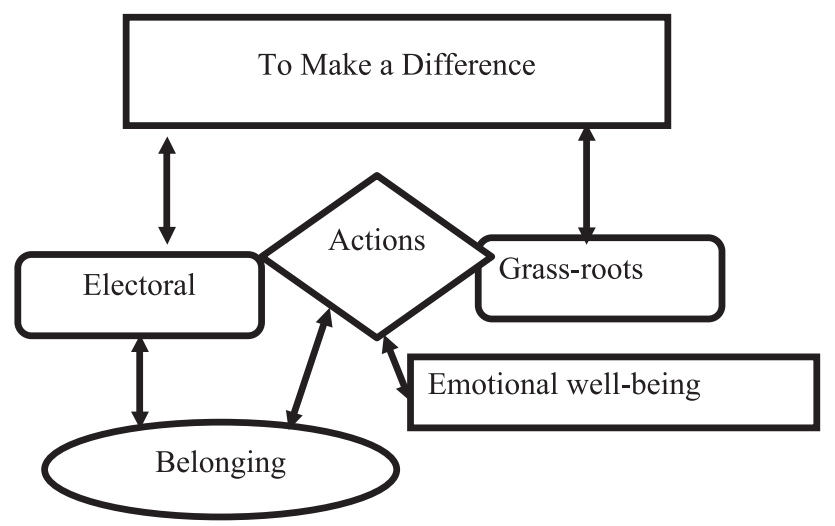

Figure 5. Participation as "making a difference" 


\section{Participation as "Self-Realization"}

This way of understanding largely reflects the newcomers' understanding of what it means to integrated into the new society. Considerable pride is taken in becoming a contributing "tax-payer" and neighbour, labels associated with economic and social integration. Still, such labels fall far short of that implied by the label "citizen" with its sense not only of being protected by the state but of having the power to shape the state. Political participation, in this sense, constitutes a striving for self-realization, a striving to be fully human. $\mathrm{H}$ ere, the implication is that this constitutes much more than just fitting in. For some study participants it means belonging, but not in a passive sense; it means seeking to actively shape and transform society for their own well-being and for that of succeeding generations.

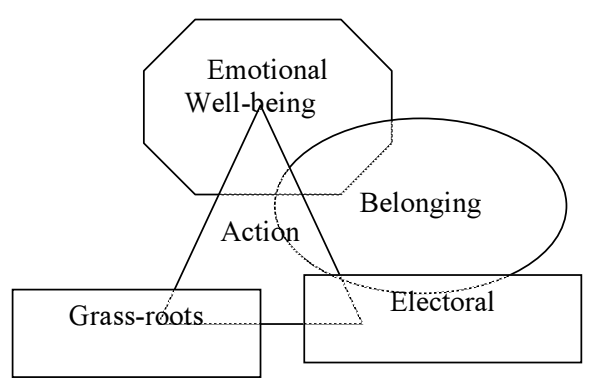

Figure6. Participation as "self-realization"

\section{Discussion}

The research findings point to a conclusion that Latin American newcomers to Canada share a conception of "integration" that encapsulates the full spectrum of economic, social and political life. W hile this image may constitute the aspiration, the findings also point to the conclusion that it is an aspiration that is not achieved in terms of its political dimension. N ewcomers possess an understanding of political participation that mirrors that of native-born Canadians but their integration into the political life of the nation was weak, especially for first generation newcomers.

The results show that the newcomers construed political participation in C anada in the form of both electoral and grass-roots politics, in an intellectual or conceptual sense. Practically speaking, the emphasis for these newcomers was more frequently on grass-roots rather than electoral participation. Certainly, they were able to articulate the virtues of grass-roots participation but this is not to suggest that high value was not placed upon the various aspects of electoral participation. Q uite simply, it would seem that in extolling the value of grass-roots politics, the newcomers are making a virtue of necessity for they see themselves largely excluded from a wide range of activities associated with electoral processes. 
The attention to grass-root politics often takes the form of community involvement. Participants report being actively involved in community organizations, such as working in food banks, volunteering in shelters for the homeless, and raising funds for diverse social causes. For example, immigrant women in the $\mathrm{H}$ alifax and Truro areas had actively created support networks among newcomers from diverse languages and nationalities. Parents in the study group have sought to instill in their children the importance of helping the needy and have encouraged them to volunteer for events when they are sponsored by the school system. In most cases, newcomer parents have been involved in volunteer activities in their home countries and they are often eager to become agents of change in their new country. For their children, participating parents often considered school-based activities to be a good training ground for helping their children learn the values associated with volunteerism and for providing a link and a connection to the new community.

All participants hold democratic values in high esteem, including the values of voting in elections, freedom of speech, and freedom to participate in non-violent demonstrations. Still, while participants accept lawful dissent as an expression of political participation, they were wary of its consequences. The participating parents encouraged adolescent and youth family members to think of non-violent and legal protest as the only legitimate expressions of dissent and would not countenance actions that might stray into the real $m$ of the illegal and/or violent.

The majority of participating parents from democratic regimes encouraged younger family members to respect and trust government officials; however, they were more circumspect about the police. Those from non-democratic countries of origin expressed little trust for either the police or government officials. In both instances, the conceptions that they carried were often related to experiences in their home countries.

Participants generally show a high degree of interest in and commitment to processes of electoral politics but many describe barriers to such participation. These barriers are based on their lack of command of either English or French, their lack of connections to the network within a political party, and prejudices they encounter from $\mathrm{C}$ anadians. These barriers foil their best intentions for a full and productive participation in electoral politics. In spite of these difficulties, there is a latent desire to become politically engaged but few talk of the possibility of assuming a leadership role such as running for public office. Their discussion of such roles focused on the barriers to their participation. Feeling themselves excluded from any leadership role, the adults in the study group, nevertheless, attached vital importance to the act of voting. Responsibility for inculcating a responsibility in their children to exercise the right to vote constituted a powerful element in their intellectual schema as did an expectation that the barriers that the adult newcomers are now encountering will not befaced by their children. Similarly, the parent group expressed an obligation to instill in their children a sense of duty and responsibility; a requirement to engage politically, at whatever level, in activities that contribute to the general good, going beyond narrow expressions of self interest. The young people showed similar commitments though insisting of confining the idea of public good to directions and values that allowed them to "follow their hearts." 
The findings of the present study al so demonstrate the existence of a highly affective component in the manner in which the newcomers construe the concept of political participation. Affective values are often cited as the motivation for participation follow your heart with passion but al ways within the boundaries of democratic channels. Positive emotions and personal fulfillment are associated with helping the needy, with volunteering in community activities to produce positive changes within the community, and with voting. Participating newcomers who do not find a welcoming environment feel hindered from actively participating in electoral politics or community organizations.

All participants express negative emotions in association with increased awareness of social injustice. H owever, these negative emotions constitute a motivational factor for further civic engagement. The majority of participants perceive that their actions "can make a difference." This perception then becomes a motive for becoming an active participant as a community worker and as a citizen casting a ballot.

Participating parents instilled in their children the importance of having passion for ideals of freedom, equality and social justice. They encouraged their children to "follow their heart." Such beliefs foster a sense of empowerment from the newcomer's point of view and will increase the probability of their active participation in $\mathrm{C}$ anadian society. The parents encourage their children and the participating adolescents and youth also encourage their peers to follow such ideals. Some parents encourage their children to fight for social justice even if such actions could place their children in an unsafe environment. All parents encourage their children to follow their ideals even if they did not agree. Some youth and adolescents encourage their peers by hel ping them carry out planned activities.

This research found an overwhelming body of evidence that civic participation does not take place in a social vacuum. There are emotional components that could hinder or facilitate diverse forms of civic participation and the creation of a new sense of belonging. The sense of belonging and identification as $\mathrm{C}$ anadian was relatively low for many of the participants. $M$ any mentioned a sense of frustration, because their voices cannot be heard as the result of having neither the connections to political parties nor a full command of the English or French language. This situation creates a lack of social connection and acceptance from the newcomer's point of view. The lack of acceptance of their political ideas and the rejection of their professional training in the $C$ anadian workplace often combined in expressions of frustration and isolation and clearly contributes to a truncated sense of belonging and integration within the fabric of the $C$ anadian society.

As expectant $C$ anadians, the study participants look forward to integration in three areas of $\mathrm{C}$ anadian life: economic life, social life, and political life. Participants aim to become independent and to be able to provide economic support for their children. They speak with pride about their ability to pay taxes and to make an economic contribution to $C$ anada's economy. Participants want to develop friendships with $C$ anadians. Parents expect their children to be accepted by their peers at school and to become involved in the social fabric of the community. With regard to political life, participants aim to become actively involved. But it is largely a limited grass-roots involvement. 
Their sense of expectation motivates them to civic engagement but many find their expectations blunted with few participants maintaining the hope of becoming involved in the full spectrum of political processes available to C anadians "by birth." Participants who failed in attempts to become involved or those who anticipate significant obstacles and therefore do not try, see barriers that are difficult to penetrate and that leave them with a sense of isolation. Their integration into $C$ anadian society is weak and such newcomers see themselves as "outsiders."

The aspirations of both C anada and the newcomers for a swift and successful integration into all aspects of life in the new society are falling short. The findings in this work demonstrate that while the new country and the newcomers share their conceptions of the meaning of political participation, the actual opportunities afforded to the newcomers who participated in this study are severely truncated. There are barriers to full participation that channel the newcomers toward a wide range of grass-roots activities and away from more formal, explicit and often more highly regarded dealings of electoral politics. O ne effect of the situation is that the newcomers are denied the sense of belonging in all its aspects. To be sure, they contribute to the economy and over time can begin to build a network of social relations, but in terms of influencing the fabric of the society in which they have chosen to live, they are confined to a supporting role with little opportunity of ever being cast as the lead character. A second major effect is that $C$ anada is denied the full value of their experience, their expertise, and perhaps above all, their commitment. When the parents in this study tell their children "hazlo de corazón" (follow your heart), they seem to be, in some ways, seeking for their children what has been denied them in both their country of origin and their chosen homeland - a belonging that embraces the full spectrum of being, whether economic, social or political.

\section{References}

Abu-Laban, Y. (1998). Welcome/STAY OUT: The contradictions of Canadian integration and immigration policies at the millennium. Canadian Ethnic Studies, 30(3), 190-211.

Bloemraad, I. (2002). The N orth American naturalization gap: An institutional approach to citizenship acquisition in the U nited States and $\mathrm{C}$ anada. International M igration Review, 36(1), 193-228.

Bruce, C. (1994). The phenomenographic interview. In R. Ballantine\& C. Bruce(Eds.), Phenomenography: Philosophy and practice (pp. 47-55). Brisbane, Australia: Q ueensland U niversity of Technology, C enter for Applied Environmental and Social Education Research.

Eisner, E. (1991). T he enlightened eye: Q ualitative inquiry and the enhancement of educational practice. N ew York: M acM illan.

Campbell, C. (2000). Betrayal and deceit: The politics of Canadian immigration. Vancouver, BC: Jasmine Books.

Greenstein, F. and Tarrow, S. (1970). Political orientations of children: T he use of a semi-projective techniquein thre nations. Beverly H ills, CA: Sage Publications.

H ardy-Fanta, C. (1993). Latina politics, Latino politics: Gender, cultural and political participation in Boston. Philadel phia: Temple University Press.

Jones-Correa, M . (1998). D ifferent paths: G ender, immigration and political participation. International M igration Review, 32(2), 326-349. 
Kalbach, M . and Kalbach,W. (1999). Becoming Canadian: Problems of an emerging identity. Canadian Ethnics Studies, 31(2), 1-16.

Kazemipur, A. and H alli, S (2000). The invisible barrier: N eighborhood poverty and integration of immigrants in Canada. Journal of International M igration and Integration, $1(1), 85-100$.

Knutson, J. (1973). H andbook of political psychology. San Francisco: Jossey-Bass.

Kvale, S. (1996). Interviews: An introduction to qualitative research interviewing. Thousands 0 aks, CA: Sage Publications.

Kymlicka, W. (2000). Is the world becoming more Canadianized? Paper presented at the Citizenship 2000 Conference, the Institute for the Study of C anada, M cG ill University, Montreal.

Kymlicka, W. (1998). Finding our way: Rethinking ethnocultural relationsin Canada. D on M ills, O N : O xford U niversity Press.

M arton, F. (1981) Phenomenography: D escribing conceptions of the world around us. Instructional Science, 10, 177-200.

M arton, F. (1996). Cognosco ergo sum. Reflections on the reflections. In G. D all'Alba \& H. Biörn (Eds.), Reflections on phenomenography: Toward a methodology? (pp. 163-202). G öthenborg, Sweden: University of G öthenborg.

$M$ ata, F. (1999). Thenon-accreditation of immigrant professionals in Canada: Societal dimensions of the problem. Paper presented to a panel discussion organized by the M aytreeFoundation during the conference "Shaping the future: Q ualifications recognition in the 21st C entury," O ctober 12-15 1999, 0 ttawa.

M ishler, W. and Clarke, H. (1990). Political participation in C anada . In M .W hittington, \& G.W illiams (Eds.), Canadian politicsin the 1990's(3rd edition) (pp.158-181). Scarborough, O N : N elson Canada.

Pendakur, K. and Pendakur, R. (1998). The colour of money: Earning differentials among ethnic groups in Canada. Canadian Journal of Economics, 31(3), 518-548.

Philip, S.D . (1976). Language development: Structure and functions. N ew York: H olt, Rinerhart $\&$ Winston.

Renström, L. (1988). Conceptions of matter: A phenomenographic approach (Atom phase). Unpublished doctoral dissertation. G öthenborg, Sweden: University of G öthenborg.

Richards, L. (1999). U sing N VIVO in Q ualitative research: Q ual itative sol uti ons and research. Australia: Scholarly, Sage Publications software.

Rumelhart, D.E and O rtony, A. (1977). The representation of knowledge in memory. In R.C Anderson, R.J. Spiro, \& W.E. M ontague (Eds.), Schooling and the acquisition of knowledge (pp.8 -17). H illdale, N J: Erlbaum.

Sears, A.M . (1996). Scarcely yet a people: State policy in citizenship education, 1947-1982. Unpublished doctoral dissertation. University of British Columbia.Vancouver.

Torney-Purta, J. (1991). Schemata theory and cognitive psychology: Implications for social studies. Theory and Research in Social Education, 19 (2), 189-210. 